Copyright (C) 2018 by Academic Publishing House Researcher

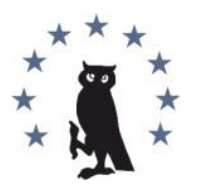

Published in the Russian Federation

European Researcher. Series A

Has been issued since 2010.

ISSN 2219-8229

E-ISSN 2224-0136

2018, 9(1): 4-8

DOI: 10.13187/er.2018.1.4

www.erjournal.ru

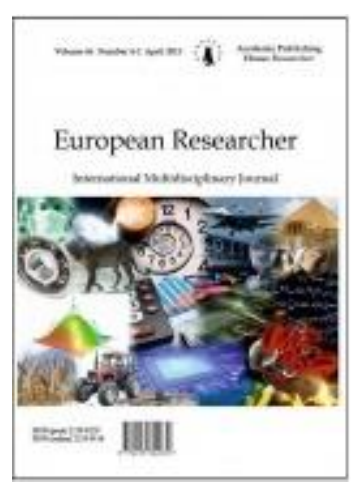

Articles and Statements

\title{
Predictors of Novelty of Product Ideas: Proposition of Theoretical Model
}

\author{
Jasminka Ahmetašević ${ }^{a},{ }^{*}$, Merdžana Obralić ${ }^{b}$ \\ a Visoka Poslovno Tehnička Škola, Bosnia and Herzegovina \\ ${ }^{\mathrm{b}}$ International Burch University, Bosnia and Herzegovina
}

\begin{abstract}
This study investigates the predictors of novelty of product ideas. Conceptual approach based on the theory has been applied to provide better understanding of the relationship between transformational leadership and two knowledge creation modes (internalization, externalization), as well as the relationship between transformational leadership and novelty of product ideas. We conducted a systematic review of literature regarding the transformational leadership and novelty of product ideas and knowledge creation modes. In the previous literature authors explored the link between transformational lidership and knowledge creation without detailed focus on knowledge creation modes. Therefore, the main contribution of this research is that it is one of the first studies to explore link between transformational leadership and novelty of product ideas, having two important knowledge creation modes as mediators. The main finding of this paper is theoretical model which should be validated by future research in order to be confirmed. Considering nature of the model, it is recommended for future research to conduct validation of the model using structural equation modelling method as the one which will provide reliable conclusions. According to proposed model based on the literature, it is expected that internalization and externalization will be mediators of the relationship between transformational leadership and novelty of product ideas.
\end{abstract}

Keywords: transformational leadership, knowledge creation modes, novelty of product ideas.

\section{Introduction}

In this paper we focus on large manufacturing companies in Federation of Bosnia and Herzegovina as sample of exploring this study in the future.

Large companies have relatively greater financial and technological resources for innovation and their resources and capabilities mean that they are better placed for innovation that require large teams, specialised equipment, large scale investment in production facilities, extensive distribution networks or relatively long-time-to-value investments (James et al., 2014).

The reason why we will focus on large manufacturing comapnies are that some studies confirm that large companies can not innovate (Wessel, 2012; Donnovan, 1994), and some say that transformational lidership help large companies working better and presented as a solution to

\footnotetext{
${ }^{*}$ Corresponding author

E-mail addresses: sppajalica@yahoo.com (J. Ahmetašević)
} 
large companie's problems (Laforet, 2008; Sayyadi, 2017). Therefore with our future investigation we would like to help large manufacturing comapnies in that way.

\section{Literature review}

In the literature review we provide review of transformational leadership and two knowledge creation modes of novelty of product ideas.

\subsection{Transformational leadership}

Zwingmann, Wegge, Wolf, Rudolf, Schmidt \& Richter (2014) representing the transformational leaders that formulate a vision to followers to focus on higher order instrinic needs and organizational goals. They inspire followers with an appeling vision, high standards and optimism about future goal attainment. Moreover, transformational leadership encourage creativity and follower's intellectual work. They found relationship between leader and employee which is characterized by trust, recognition and confidence.

Nemaei (2012) \& Choudhary, Akhtar \& Zaheer (2013) described transformational leaders as individuals who increase confidence, awareness, interest and motivation in the followers by moving the follower's interest from their personal existance to the existance the organizational group. Chen \& Chang (2013) belived that transformational leadership can facilitate the introduction of new ideas by providing vision, motivation and intellectual stimulation to follower. Therefore employee are motivated with this style of leadership. This kind of leadership is positively related with organizational innovation. They create teams of innovative people, promoting mutual trust and creating shared vision among followers.

Innovation requires implementation of the ideas, selling ideas within organization to other. In one top telecommunication organization in Pakistan showed that transformational leadership had a significant on organization innovation (Khan et al., 2009).

Transformational leadership motivate follower to accomplish more than the follower planned to accomplish. It can enhance innovation by motivating and encouraging employees to think creatively (Givens, 2008; Chen, Chang, 2013).

Hypia \& Parjanen (2013) found that generation of new ideas could be implemented by single or joint efforts (two or more) employees. In other hand transformational leadership promotes group creativity. Phipps, Prieto \& Verma (2012) stated that group brainstorming is useful technique for generation of novel and innovative ideas. It can be useful for transformational leadership which may be more effective at creating and sharing knowledge at the individual and group levels (Bryant ,2003). Jaiswal \& Dhar (2015) defined when everyone in an organization is creative, it help them become a creative organization.

Zagoršek, Dimovski \& Škerlavaj (2009) argue that the transformational leadership encourage communication between team member. They encourage the expression of different views and ideas. Transformational leadership has been shown to impact collective team outcomes, through collective within- team behaviors, include studies that have demonstrate transformational leadership behaviors increase work outcomes via motivation and goal commitment (Hoch, 2013).

\subsubsection{Transformational leadership and knowledge creation}

Previous work has indicated the relationship between transformational leadership and knowledge creation (Mitchell, Boyle, 2009; Tse, Mitchell, 2010; Bryant, 2003; Hayat et al., 2015; Singh, 2008; Zagoršek et al., 2009). Finding of their studies showed that transformational leadership has positive significant effect on knowledge creation. Considering concepts claimed above the following hypotheses are proposed:

H1: Transformational leadership has significant impact on Internalization.

H2: Transformational leadership has significant impact on externalization.

\section{modes}

2.1.2 Transformational leadership and novelty of product ideas with knowledge

Biransnar, Albufalasa \& Bader (2013) revealed the function of „, Transformational leadership“ and „Knowledge management process“ on predicting product and process innovation. The results demonstrate that knowledge transfer and application partially mediated the relationship between transformational leadership and product innovation. Therefore the following hypotheses are presented:

H3: Internalization mediates relationship between transformational leadership and novelty of product ideas. 
H4: Externalization mediates relationship between transformational leadership and novelty of product ideas.

\subsubsection{Transformational leadership and novelty of product ideas}

There are many researchers who elaborated the influence of transformational leadership and innovation (Afsar, Badir and Saeed, 2014; Jaiswal and Dhar, 2005; Mokhber, Ismail \& Vakilbashi, 2015; Hyypia \& Parjanen, 2013; De Jong and Den Hartog, 2007; Bryant, 2003). Afsar, Badir and Saeed (2014) found that transformational leadership positively influence on the innovative work behavior (IWB) which includes idea generation. Jaiswal and Dhar (2005) investigated the link between innovation and creativity. Some researchers showed positive relationship between transformational leadership and employees (De Jong and Den Hartog, 2007; Bryant, 2003). They defined employees as productive when they have the freedom to create new ideas. After creating their ideas, they share ideas with coworkers and test out their new ideas. The study of Mokhber, Ismail \& Vakilbashi (2015) and Hypia \& Parjanen (2013) developed that transformational leadership positively related to the organizational innovation. Thus, based on the previous studies, the hypothesis of this study is as follows:

H5:Transformational leadership has significant impact on novelty of product ideas.

\subsection{Internalization}

Internalization is the process of explicit knowledge created and shared throughout organization and converted into tacit knowledge (Nonaka, Toyama and Konno, 2000). There are many authors who investigated relationship between internalization and novelty of product ideas (Lee and Choi, 2003; Schuzle and Hoegl, 2008). Studies have shown that internalization positively influences on the novelty of product ideas. Hence, this study infers the following assumption:

H6: Internalization has significant impact on the novelty of product ideas

\subsection{Externalization}

Externalization is the process of converting tacit knowledge into explicit knowledge (Nonaka et al., 2000). Thomas (2003) realized open innovation that is use of external ideas as well as internal ideas. He stress that open innovation includes customer, suppliers, universities and so on. In that way open innovation has idea generation as a key step (Vrgović et al., 2013). There are many authors who investigated link between externalization and novelty of product ideas (Lee, Choi, 2003; Schuzle, Hoegl, 2008; Kanapathy et al., 2014). Lee and Choi found positive relationship, while Schuzle and Hoegl found negative relationship between externalization and novelty of product ideas. Authors such as Kanapathy, Khong and Dekkers (2014) found positive relationship between external source of ideas called supplier involvement practice and new product development. The study proposes the following hypothesis:

H7: Externalization has significant impact on the novelty of product ideas

Proposed theoretical model is presented in Figure 1 below.

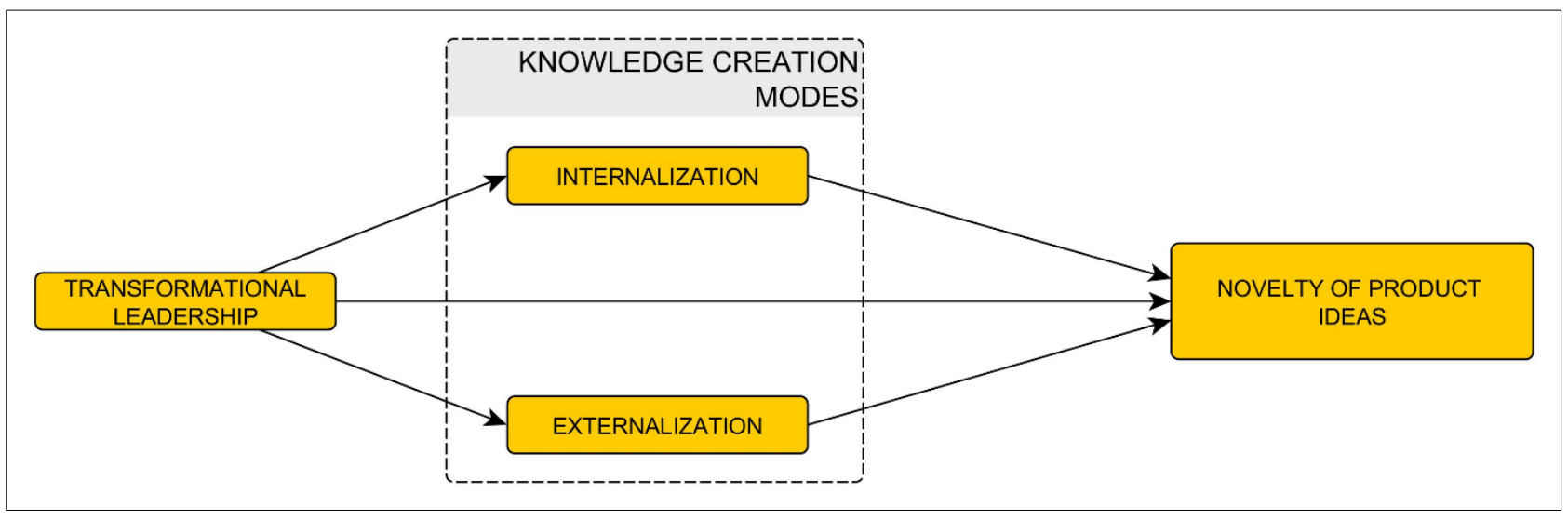

Fig. 1. Proposed theoretical model

\section{Methodology}

In this study we did not test the model, but we suggest and recommend using Structural Equation Modelling method. According to the literature our expectations are that hypotheses will 
be accepted. Relevant suggestion for future reseachers and pratitioners will be given after processing model and explaning the results.

\section{Conclusion}

Based on the literature dealing with transformational leadership, knowledge creation modes (internalization, externalization) and generating ideas for new product development, the one can conclude that transformational leadership and two knowledge creation modes may serve as important predictors of the dependent variable. In total, proposed theoretical model suggests seven hypotheses to be tested. Both direct and indirect effects can be expected to occur between Transformational leadership and novelty of product ideas, according to the model. Transformational leadership is expected to motivate followers by encouraging communication between them and facilitating the introduction of new ideas. Internalization and externalization are expected to be mediating the relationship between Transformational leadership and novelty of product ideas. Future studies should give efforts to provide empirical evidence for this model, and hereby all scientific researchers in this area are kindly encouraged to validate this model in different samples.

\section{References}

Afsar et al., 2014 - Afsar, B., Badir, F., Saeed, B. B. (2014). Transfromational leadership and innovative work behavior. Emerald Group Publishing limited 114 (8), pp. 1270-1300.

Birasnav et al., 2013 - Birasnav, M., Alnbufalasa, M., Bader, Y. (2013). The roles of transfromational leadership and knowledge management processes on predicting product and process innovation: An empirical study developed in Kingdom of Bahrain, 11 (12), pp. 64-75.

Bryant, 2003 - Bryant, S.E. (2003). The role of transformational and transactional leadership in creating, sharing and exploiting organizational knowledge. Journal of leadership and organizational studies, 9 (4).

Chen, Chnag, 2013 - Chen, Y.S., Chang, C.-H. (2013). The determinants of green product development performance: green dynamic capabilitis, green transformational leadership, and green creativity. Journal of Business Ethics, 116 (1), pp. 107-119.

Choudhary et al., 2013 - Choudhary, A. I., Akhtar, S. A., Zaheer, A. (2013). Impact of trnasfromational and servant leadership on organizational performance. A comparative analysis. Journal of business ethics. 116 (2), pp. 433-440.

De Jong, Den Hartog, 2007 - De Jong, J. P. J., Den Hartog, D. N. (2007). How leaders influence employees' innovative behaviour. European Journal of innovation, 10 (1), pp. 41-64.

Donovan, 1994 - Donovan. S.S. (1994). New Product Development in Small and Large Companies. R \& D. Vol.3. No. 9.

Givens, 2008 - Givens, R.J. (2008). Transformational leadership: the impact on organiizational and personal outcomes. Emerging leadership journeys 1, pp. 4-24. ISSN 19414684.

Hayat et al., 2015 - Hayat, A, Hasanvand, M. M., Nikakhlag, S., Dehghani, M. R. (2015). The role of transformational leadership and its knowledge management processes. Journal of Health Management \& Informatics, 2 (2).

Hoch, 2013 - Hoch, J.E. (2013). Shared Leadership and Innovation: The role of vertical leadership and employee integrity. Journal of Business and Psychology, 28 (2), pp. 159-174. Springer.

Hyypia, Parjanen - Hyypia, M., Parjanen, S. (2013). Boosting creativity with transformational leadership in fuzzy front-end innovation process. Interdisciplinary Journal of Informaitons, Knowledge, and Management 8.

Jaiswal, Dhar, 2015 - Jaiswal, N.K., Dhar, R.L. (2015). Transformational leadership, innovation climate, creative self -efficacy and employee creativity: A multilevel study. International Journal od Hospitality Management 51, pp- 30-41.

James et al., 2014 - James, A., Gee, S., Love, J. H., Roper, S., Wills, J. (2014). Small firmlarge firm relationships and the implications for small firm innovation: what do we know? Enterprise Research Centre 9. 
Kanapathy et al., 2014 - Kanapathy, K., Khong, K. W., Dekkers, R. (2014). New product development in an emerging economy: Analysing the role of supplier involvmnet practices by using bayesian markov chain monte carlo technique. Journal of Applied Mathematics, Article ID 542303, pp. 12.

Khan et al., 2009 - Khan, R., Rehman, U. A., Fatima, A. (2009). Transformational leadership and organizational innovation: „Moderated by organizational size“. African Jorunal of Business Management, 3 (11), pp. 678-684.

Laforet, 2008 - Laforet, S. (2008). Size, Strategic, and market orientation affects on innovation. Journal of Business Research, 61, pp. 753-764.

Lee, Choi, 2003 - Lee, H., Choi, B. (2003). Knowledge management enablers, processes, and organizational performance: and integrative view and empirical examination. Journal of Management Information Systems, 20 (1), pp. 179-228.

Mitchell, Boyle, 2009 - Mitchell, R.J., Boyle, B. (2009). A theoretical model of transformational leadership's role in diverse teams. Leadership \& Organization Development Journal, 30 (5), pp. 455-474.

Mokhber, 2015 - Mokhber, M., Ismail, W. K. bin W., Vakilbashi, A. (2015). Effect of trnasformational leadership and its components on organizational innovation. Journal of Management Studies, 8 (2), pp. 221-241.

Nemaei, 2012 - Nemaei, B. (2012). The imapct of participative leadership on employee's motivation, job satisfaction and innovation. Dissertation. British Univesrity. Dubai.

Nonaka, Konno, 1998 - Nonaka, I., Konno, N. (1998). The concept of „ba“: Building a foundation for knowledge creation. California management review, 40 ( 3).

Nonaka et al., 2000 -Nonaka, I., Toyama, R., Konno, N. (2000). SECI, Ba and leadership: a unified model of dynamic knowledge creation. Japan 33, pp. 5-34.

Phipps, 2012 - Phipps, S. T. A., Prieto, L. C., Verma, S. (2012). Holding the helm: exploring the influence of transformational leadership on group creativity, and the moderating role of organiizational learning culture. Journal of Organizational Culture, Communication and Conflicts, 16 (2).

Sayyadi. 2017 - Sayyadi, M. (2017). Leading Performance in Large Companies. The CEO Magazine.

Schuzle, 2008 - Schuzle, A., Hoegl, M. (2008). Organizational knowledge creation and the generation of new product ideas: A behavioral approach 37, pp. 1742-1750.

Singh, 2008 - Singh, K. (2008). Relationship between learning organization and transformational leaderhsip: banking organization in India. Relationship between learning organization and transformational leadership. Journal of Business and Management Science. ISSN 1985-692X.

Thomas, 2013 - Thomas, E. (2013). Supplier integration in new product development: Computer mediated communication, knowledge exchange and buyer performance. Industrial Marketing Management 42, pp. 890-899.

Tse, 2010 - Tse, H. M., Mitchell, R. (2010). A theoretical model of transformational leadership and knowledge creation. The role of open-mindedness norms and leader-member exchange. Journal of Management \& Organization, 16 (1), pp. 83-99.

Vrgović et al., 2013 - Vrgović, P., Kovačević, J., Vrgovović-Jošanov, I. (2013). Effects of stimulating communication on customers' idea generation processes. International Journal of Engineering. Romania. ISSN 1584-2665.

Wessel, 2012 - Wessel, M. (2012). Why Big Companies Can't Innovate. Product Development. Hard Business Review.

Zagoršek et al., 2009 - Zagoršek, H., Dimovski, V., Škerlavaj (2009). Transactional and transformational leadership impacts on organizational learning. Journal of Eat European Management Studies, 14 (2), pp. 144-165.

Zwingmann et al., 2014 - Zwingmann, I., Wegge, J., Wolf, S., Rudolf, M., Schmidt, M., Richter, P. (2014). Is trnasformational leadership helathy for employees? A multilevel analysis in 16 nations. Journal of research in human. Health promotion through leadership, pp. 24-51. 